\title{
Characterization of fermented broccoli (Brassica oleracea L.) and spinach (Amaranthus sp.) produced using microfiltration membrane as folic acid source for smart food formula
}

\author{
Agustine Susilowati ${ }^{1 *}$, Aspiyanto $^{1}$ and Hakiki Melanie ${ }^{1}$ \\ ${ }^{1}$ Research Center for Chemistry, Indonesian Institute of Sciences, 15315 Tangerang Selatan, Indonesia
}

\begin{abstract}
Purifying and drying both fermented biomasses of broccoli (Brassica oleracea L.) and spinach (Amaranthus sp.) by Kombucha culture has been conducted to recover concentrate and powder of folic acid. The aims of this study is to determine the differences of particles characteristics and compositions of concentrate and powder from both mentioned folic acid source through Micro Filtration (MF) membrane and without MF membrane. The best folic acid produced by MF membrane process (room temperature, stirrer rotation speed $400 \mathrm{rpm}$, pressure $40 \mathrm{psia}$ and 30 minutes) and drying $\left(30{ }^{\circ} \mathrm{C}, 22 \mathrm{~cm} \mathrm{Hg}\right.$ and 24 hours) were resulted in biomass of the concentrate and powder with compositions of total solids $6.29 \%$ and $96.91 \%$, total polyphenol $0.25 \%$ and 0.06 $\%$, folic acid $58.8 \mu \mathrm{g} / \mathrm{mL}$ and $54.33 \mu \mathrm{g} / \mathrm{mL}$, reducing sugar $105.34 \mathrm{mg} / \mathrm{mL}$ and $441.39 \mathrm{mg} / \mathrm{mL}$, and total acids $0.57 \%$ and $2.33 \%$, respectively. In optimum condition, fermented spinach concentrate contributed to particles distribution with diameter size $(\varnothing)$ between 0,4 and $100 \mu \mathrm{m}(75.45 \%)$, and with $\varnothing$ between 100 and $1000 \mu \mathrm{m}(26.3 \%)$, otherwise, the process without MF membrane was resulted the particles distribution respectively $74.1 \%$ and $25.9 \%$ by each interval of $\varnothing$.
\end{abstract}

\section{Introduction}

Broccoli (Brassica oleracea L.) and spinach (Amaranthus sp.) fermented by Kombucha culture have potential utilization as food functional fortificant as folic acid source to enhance brain smartness and prevent anaemia [1]. Novelty aspect of this fermentation process is based on ability of Kombucha culture in degrading tea polyphenol during preparation of Kombucha tea [2, 3, 4].

Potential exploration of folic acid in spinach (Amaranthus sp.) will make this commodity as alternative resource of natural folic acid. Polyphenols contained in broccoli and spinach are source of folic acid produced by activity of microbes in Kombucha culture through de novo biosynthesis [5] in amino acids (adenine, hisyidine, methionine) from Kombucha culture (fungi, bacteria, yeast) and tea leaves.

This biosynthesis involves enzyme activities of dihydrofolate synthase (DHFS) and ypolyglutamate synthease (FPGS) to form dihydrofolate and polyglutamate folate, a derivative of folic acid [5], in which this process is occurred only on plant and microbe [6]. Kombucha cultures containing Acetic Acid Bacteria, such as Acetobacter xylinum and yeast, such as Saccharomyces cereviseae, Saccharomyces ludwigii, Saccharomyces bisporus, Zygosaccharomyces sp. and various type of khamir (Torolupsis sp.) [7] could possibly degrade polyphenol and amino acids in broccoli and spinach. It has been known that there are more than eight types of specific enzymes from plant, which have important roles in this synthesis, particularly esterification of $\rho \mathrm{ABA}$ with glucose [8].<smiles>Nc1nc(O)c2nc(CNCc3ccc(C(=O)NC(CCC(=O)O)C(=O)O)cc3)ncc2n1</smiles>

Fig. 1. Chemical Structure of Folic Acid

Process of concentrating biomass for both fermented broccoli and spinach through MF membrane $(0.15 \mu \mathrm{m})$ equipped in dead-end stirred microfiltration cell (DESMFC) produces concentrate and permeate with different specification. MF membrane retains more folic acid in concentrate than in permeate, although particle size of folic acid is smaller than pore size in MF membrane used $(0.01 \mu \mathrm{m}<0.15 \mu \mathrm{m})$ [9]. Its occurrence of fouling is possibly caused by operation condition factors such as pressure and time, membrane type, characteristic of biomass $[10,11]$. In drying process of biomass concentrate using vacuum dryer at $30^{\circ} \mathrm{C}$ for 24 hours and biomass without MF membrane process as

* Corresponding author: agustine_1408@yahoo.co.id 
comparison, recovery of powder affect on composition, particles size and distribution. For smaller particles size and larger particles distribution enable better surface tension recovery on formulation so that it facilitates application process on functional property in ability of adsorption of folic acid by body.

The aims of this experimental study was to determine the differences of particles characteristic and distribution of particles size, and compositions of concentrate and powder from both fermented broccoli and spinach by Kombucha culture as folic acid source through MF membran and without MF membrane as in biomass

\section{Experimental details}

\subsection{Materials, equipments and analysis instrument}

Main materials used in this experimental work were fresh green spinach (Amaranthus sp.) and broccoli (Brassica oleracea L.) purchased from local market, sucrose, Kombucha culture (Research Centre for Chemistry - LIPI), $0.15 \mu \mathrm{m}$ microfiltration (MF) membrane (FSM-0.15-PP, Danish Separation Systems, Denmark), distilled water, and chemicals for preparation and analysis purposes. All of the chemical reagents used were of analytical grade quality.

The main equipment used in this experimental work were glassware (cylinder glass, beaker glass, erlenmeyer flask, stoppered conical flask), high precision balance (Fujitsu, Japan), fermentation system in laboratory scale (local), laminar flow chamber (local), incubator (local), blender, sieves of 60 mesh and 80 mesh (Retsch, Germany), magnetic stirrer (HI 303 N, HANNA Instrument, Japan), pressure gauge of nitrogen (Fisher Scientific Company, England), cylindrical tank for nitrogen (local), stop watch (Hanhart Profil 2, Germany), Dead-End Stirred Ultrafiltration Cell (DESUFC) (Amicon, Model 8200, MILLIPORE, U. S. A.), vacuum dryer (Vacutherm, Heraus Type VT 6060 P, Kendro Laboratory Products, Germany), and porcelain mortar \& pestle (Z247529-1EA, SIGMA-ALDRICH). Analysis instruments were UV-Vis Spectrophotometer (Model RF-550, Shimadzu, Japan) and Particle Size Analyzer (Beckman Coulter LS 100 Q, U. S. A.).

\subsection{Experimental design and analysis}

Experimental work performed by using biomass filtrates of fermented broccoli and spinach by Kombucha culture which were filtered via 80 mesh and further purified by MF membrane $(0.15 \mu \mathrm{m})$ equipped in DESMFC and resulted in retentate (concentrate) and permeate [12]. Analyses were carried out on total solids (Gravimetric method), total acids (Titrimetric method), reduction sugars (Somogyi Nelson method) [13], total polyphenol (Folin-Denis method) [14], folic acid (UV-Vis
Spectrophotometer) [15] and particles distribution (LS Particle Size Analyzer) (Bacman Coulter). Process and analysis were conducted in duplicate. Data were processed in descriptive analysis based on average values.

\subsection{Process steps}

\subsubsection{Fermentation process}

Fermentation process of fresh broccoli was subsequently blanched at $80{ }^{\circ} \mathrm{C}$ for 5 minutes, water was added at Brocolli to water ratio 1 part : 4 parts, pulverized and filtered via a 80 mesh sieve to produce filtrate and residue. The broccoli filtrate was then used as substrate in fermentation process. In this fermentation process, substrate was added as inoculum of broccoli (15 $\%, \mathrm{v} / \mathrm{v}$ vegetable filtrate) [9], sucrose $10 \%$ added (w/v filtrate) and stored in closed container using cloth followed by aeration in dark room at room temperature for 6 days. The whole fermentation activities were aseptically. Both similar method and concentrations of inoculum of vegetable and sucrose was applied for spinach for 15 minutes. Results of these fermentation processes were fermented broccoli and spinach. Recovery of each biomass were used as feed in purifying process of folic acid through MF membrane $(0.15 \mu \mathrm{m})$.

\subsubsection{Purifying and drying processes}

A number of fermented broccoli suspension was filtered through 80 mesh sieve, and filtered via $0.15 \mu \mathrm{m} \mathrm{MF}$ membrane fitted in DESMFC at stirrer rotation speed $400 \mathrm{rpm}$, room temperature and pressure 40 psia for 30 minutes. Same method and process condition were done for fermented spinach suspension. The result of MF membrane process on fermented broccoli suspension were retentate of fermented broccoli or spinach (concentrate) and then dried using vacum at $30^{\circ} \mathrm{C}$ for 24 hours, reduced size and sieved via 60 mesh. The flowchart of the overall process is shown in Figure 2.

\subsubsection{Folic acid analysis}

Analysis of folic acid was done by using spectrophotometer method according to reaction of diazotization acid p-aminobenzoylglutamic yielded after reduction reaction of folic acid and 3-aminophenol to form yellow-orange complex. One (1) $\mathrm{mL}$ of standard folic acid or sample was subsequently added by $1 \mathrm{~mL}$ of Hydrochloric (4 M), $1 \mathrm{~mL}$ of Sodium Nitrite $1 \%(\mathrm{w} / \mathrm{v})$, $1 \mathrm{~mL}$ of Sulfamic Acid $1 \%(\mathrm{w} / \mathrm{v})$ and $1 \mathrm{~mL}$ of 3Aminophenol $1 \%(\mathrm{w} / \mathrm{v})$ and then vortexed to form yellow-orange complex. Further, absorbance was measured by using UV-Vis Spectrophotometer at wavelength of $460 \mathrm{~nm}$ [15]. 




Fig.2. Flow diagram of recovery of fermented broccoli and spinach concentrate powders via microfiltration membrane process.

\section{Results and discussion}

\subsection{Effect of purifying fermented biomass of broccoli and spinach by Dead-End Stirred Microfiltration Cell (DESMFC)}

Both broccoli and spinach fermented by kombucha culture were produced through blanching, pulverizing, sieving via 100 mesh and fermentation in closed container and dark room at room temperature for 6 days and 3 days, respectively [9]. Purifying process on biomass using MF membrane (pore size $0.15 \mu \mathrm{m}$ ) fitted in dead-end stirred microfiltration cell (DESMFC) at stirrer rotation speed $400 \mathrm{rpm}$, room temperature and pressure 40 psia for 30 minutes were resulted in retentates (concentrates) of fermented broccoli and fermented spinach as thick suspension with brownish yellow and brownish turbid, as represented in Figures 3.

Purification process of fermented vegetables produced recovery of folic acid in concentrates of fermented broccoli $(88.14 \%)$ and fermented spinach $(89.18 \%)$ when compared to retentate and permeate. When compared to folic acid in fermented broccoli and fermented spinach feeds, this purification process was able to separate folic acid in concentrates, namely from
$43.10 \mu \mathrm{g} / \mathrm{mL}$ to $28.1 \mu \mathrm{g} / \mathrm{mL}$ ( $65.2 \%$ or 0.65 folds) and from $54.83 \mu \mathrm{g} / \mathrm{mL}$ to $58.90 \mu \mathrm{g} / \mathrm{mL}(107.72 \%$ or 1.07 folds). Purification process also showed difference in compositions of component in retentate (concentrate) and permeate, in which DESMFC was able to retain more total solids, folic acid and reducing sugars in retentate (concentrate), but not able to retain total polyphenols and total acids in which it was passed freely across as permeate. Selectivity of MF membrane has significant effect on compositions of retentate (concentrate) and permeate and it is affected by operation condition, such as stirrer rotation speed, temperature, pressure, time and material type [16].
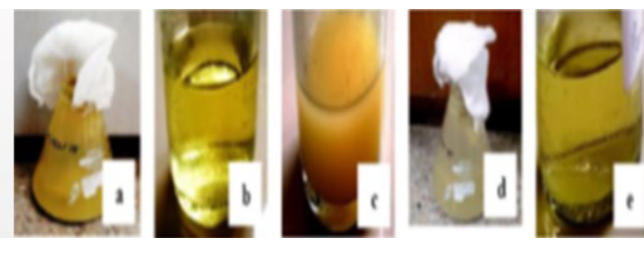

Fig. 3 (a) Spinach fermented for 3 days, (b) permeate (extract) and (c) retentate (concentrate) of fermented spinach as a result of MF $(0.15 \mu \mathrm{m})$ membraneprocess, (d) broccoli fermented for 6 days, (e) permeate (extract) and (f) retentate (concentrate) of fermented broccoli as a result of MF $(0.15 \mu \mathrm{m})$ membrane process.

Table 1. Composition of fermented broccoli and spinach as feed and as a result of purification via $0.15 \mu \mathrm{m}$ MF membrane.

\begin{tabular}{|l|c|c|c|c|c|}
\hline \multirow{2}{*}{\multicolumn{1}{|c}{ Types of Material }} & \multicolumn{5}{c|}{ Composition } \\
\cline { 2 - 6 } & $\begin{array}{c}\text { Total Solid } \\
(\%)\end{array}$ & $\begin{array}{c}\text { Total } \\
\text { Polyphenol(\%) }\end{array}$ & $\begin{array}{c}\text { Folic Acid } \\
(\boldsymbol{\mu g} / \mathbf{m L})\end{array}$ & $\begin{array}{c}\text { Reducing } \\
\text { Sugar }(\mathbf{m g} / \mathbf{m L})\end{array}$ & $\begin{array}{c}\text { Total Acid } \\
(\%)\end{array}$ \\
\hline Fermented broccoli (6 days)/Feed & 5,60 & 0,05 & 43,10 & 96,51 & 0,10 \\
\hline Fermented broccoli concentrate $(* *)$ & 5,76 & 0,06 & 28,10 & 66,09 & 0,93 \\
\hline Fermented broccoli permeate & 3,60 & 0,07 & 3,78 & 43,38 & 0,82 \\
\hline Fermented spinach (3 days)/Feed & 7,90 & 0,07 & 54,83 & 86,30 & 0,58 \\
\hline Fermented spinach concentrate $(* *)$ & 6,29 & 0.25 & 58,90 & 105,34 & 0,57 \\
\hline Fermented spinach permeate & 8,25 & 0,08 & 7,14 & 116,43 & 0,47 \\
\hline
\end{tabular}




\subsection{Effect of drying on composition of fermented broccoli and spinach}

Drying process at vacuum $22 \mathrm{~cm} \mathrm{Hg}$ and $30{ }^{\circ} \mathrm{C}$ for 24 hours by vacuum dryer produced both fermented broccoli and spinach with different composition, as illustrated in Figure 4. Drying process increased total solids concentration on both fermented broccoli and spinach concentrates as a result of MF membrane process from $5.76 \%$ to $94.37 \%(92.83 \%)$ and from $6.28 \%$ to $96.43 \%$ (93.48\%), respectively. Total solids concentration are not different compared with recovery of total solids from biomass without MF membrane process, namely $93.55 \%$ and $96.91 \%$. Total solids of biomass are accumulation of the whole solids both soluble and insoluble [13].

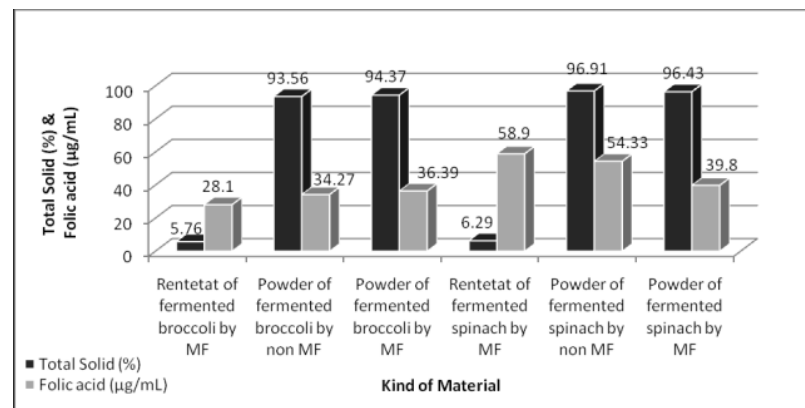

Fig. 4 Effect of drying on total solids and folic acid in both fermented broccoli and spinach with and without through MF membrane process

Different pattern observes on folic acid content, in which the concentrate of fermented broccoli produced via MF membrane pressure increase from $28.1 \mu \mathrm{g} / \mathrm{mL}$ to $36.4 \mu \mathrm{g} / \mathrm{mL}$ (29.54 \%), higher than recovery of folic acid in powder from biomass without MF membrane processes $(34.27 \mu \mathrm{g} / \mathrm{mL})$. Whereas, in biomass of fermented spinach, folic acid decrease from $58.1 \mu \mathrm{g} / \mathrm{mL}$ to $39.8 \mu \mathrm{g} / \mathrm{mL}(31.5 \%)$, and become lower than recovery of folic acid in powder from biomass without MF membrane processes $(54.339 \mu \mathrm{g} / \mathrm{mL})$. Fermented spinach possibly contain more than fermented broccoli in which same drying process condition gave different evaporation rate. At the same time, folic acid is integrated with other components. Folic acid was not stable, particularly when being exposed to heating, light and mechanic activation [17].

Drying process also increased organic acids as total acids, but decreased total polyphenol both fermented broccoli and fermented spinach, as represented in Figure 5. Increasing total acids concentration on fermented broccoli and fermented concentrate powders processed via MF membrane were from $0.93 \%$ to $4.67 \%$ ( 402.15 $\%$ or 4 folds) and from $0.57 \%$ to $2.33 \%$ (308.77 \% or 3 folds). When compared to total acids from biomass without MF membrane process, these total acids concentration are similar with concentration of total acids in biomass concentrate powder without MF membrane, namely $4.67 \%$ and $2.33 \%$. This is possibly caused by organic acids linked strong on solutes so that raising total solids would increase total acids concentration, as well. Total acids are all organic acids produced as metabolite by invertase enzyme activity of microbes, in which sugars are fermented to form organic acids and further to form alcohol [3.4]. Organic acids contribute fresh aroma in biomass like as fruit aroma.

Drying process increased reducing sugars for both concentrates of fermented broccoli and spinach as a result of MF membrane processes from $66.09 \mathrm{mg} / \mathrm{mL}$ to $412.18 \mathrm{mg} / \mathrm{mL}$ ( $523.66 \%$ or 5.23 folds) and from 105.34 $\mathrm{mg} / \mathrm{mL}$ to $545.59 \mathrm{mg} / \mathrm{mL}$ (417.93\% or 4.18 folds). Reducing sugars in fermented broccoli was lower than reducing sugar in powder from biomass without MF membrane process $(537.60 \mathrm{mg} / \mathrm{mL})$, however it was higher than in powder of biomass without MF membrane process $(441.39 \mathrm{mg} / \mathrm{mL})$.

Drying process also showed higher concentration of total polyphenol in fermented spinach powder $(0.05 \%)$ than in fermented broccoli powder $(0.04 \%)$. Based on the results of overall processes, it shown that fermented spinach produced better total polyphenol than fermented broccoli both with and without MF membrane process. Total polyphenols are all polyphenols compound and their derivatives from both vegetables type, in which their concentrations would decrease with longer fermentation time [9]. A reduction of total polyphenols were caused by heat conductive during drying process, as well.

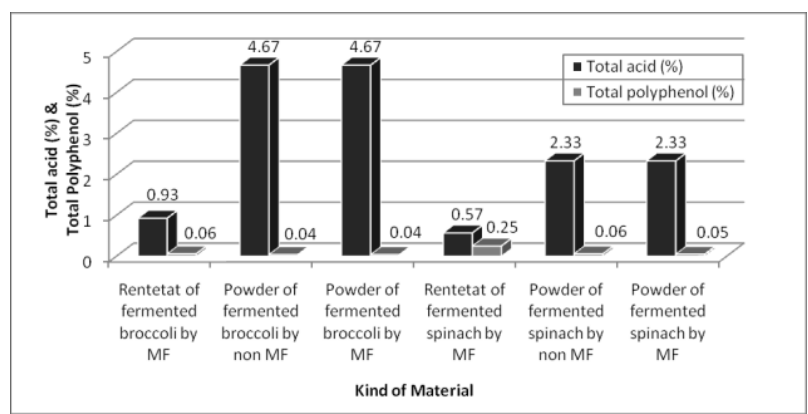

Fig. 5 Effect of drying on total acids and total polyphenol in both fermented broccoli and spinach with and without through MF membrane process.

Drying process also raise reducing sugars from both types of biomass, as demonstrated in Figure 6. Reducing sugar is all of sugars as a result of fermentation, which has reduction property as metabolite.

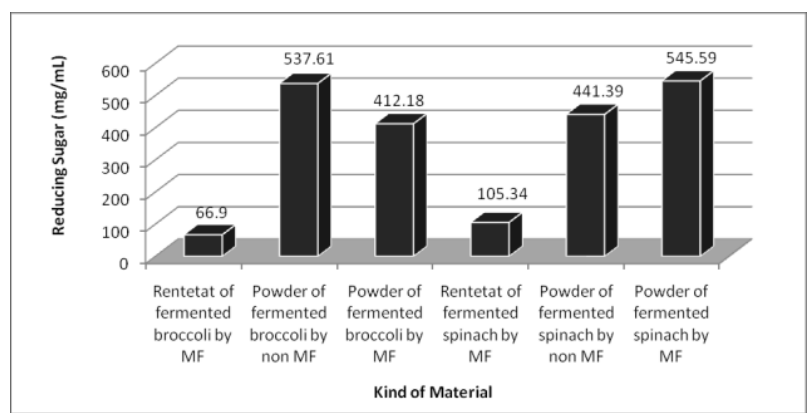

Fig. 6 Effect of drying on reducing sugars in both fermented broccoli and spinach with and without through MF membrane process.

Kombucha culture produce glucose as source of carbon to metabolite, however not of all glucose was fermented by various factors, particularly microbes 
internal factors and fermentation condition (temperature and time) and substrate type.

Reducing sugars in powder from both concentrates of fermented broccoli and spinach are increased as a result of MF membrane processes from $66.09 \mathrm{mg} / \mathrm{mL}$ to $412.18 \mathrm{mg} / \mathrm{mL}$ ( $523.66 \%$ or 5.23 folds) and from 105.34 $\mathrm{mg} / \mathrm{mL}$ to $545.59 \mathrm{mg} / \mathrm{mL}$ (417.93 \% or 4.18 folds). Reducing sugars in fermented broccoli was lower than reducing sugar in powder from biomass without MF membrane process $(537.60 \mathrm{mg} / \mathrm{mL})$, however it has higher content compared with reducing sugar in powder of biomass without MF membrane process (441.39 $\mathrm{mg} / \mathrm{mL}$ ).

\subsection{Characteristics of particles of fermented broccoli and spinach concentrates}

Purification process on fermented broccoli and fermented spinach through MF membrane process produced concentrates of biomass with different particles characteristic with biomass without via MF membrane process, as shown subsequently in Figures 7 and Figure 8.

\subsubsection{Fermented Broccoli}

Particles distribution on biomass of fermented broccoli without MF membrane process in Figure 7a has no particles with diameter size $(\varnothing)$ ranging from $0.4 \mu \mathrm{m}$ to $1 \mu \mathrm{m}$ or $<1 \mu \mathrm{m}(0 \%)$, but there are particles with $\varnothing<$ $10 \mu \mathrm{m}$ or between $0.4 \mu \mathrm{m}$ and $10 \mu \mathrm{m}(47.5 \%)$, particles with $\varnothing<100 \mu \mathrm{m}$ or between $0.4 \mu \mathrm{m}$ and $100 \mu \mathrm{m}(100$ $\%)$ and particles with $\varnothing<1000 \mu \mathrm{m}$ or between $0.4 \mu \mathrm{m}$ and $1000 \mu \mathrm{m}(100 \%)$ from $100 \%$ of material volume. In other words, $47.5 \%$ of concentrate is particles with $\varnothing$ between $0.4 \mu \mathrm{m}$ and $100 \mu \mathrm{m}$, and particles with $\varnothing>100$ $-1000 \mu \mathrm{m}$ or the whole particles were dominated by particle with $\varnothing<100 \mu \mathrm{m}$. Particles distribution in biomass of fermented broccoli concentrate, as shown in Figure $7 \mathrm{~b}$ from result of MF membrane at stirrer rotation speed $400 \mathrm{rpm}$, room temperature and pressure 40 psia for 30 minutes indicated subsequently particles with $\varnothing$ between $0.4 \mu \mathrm{m}$ and $1 \mu \mathrm{m}$ or $<1 \mu \mathrm{m}(2.15 \%)$, particles with $\varnothing<10 \mu \mathrm{m}$ or between 0.4 and $10 \mu \mathrm{m}(24.1 \%)$, particles with $\varnothing<100 \mu \mathrm{m}$ or between $0.4-100 \mu \mathrm{m}$ (49.2\%) and particles with $\varnothing<1000 \mu \mathrm{m}$ or between 0.4 $-1000 \mu \mathrm{m}(100 \%)$ from $100 \%$ of material volume. In other words, $75.45 \%$ of concentrate is particles with $\varnothing$ between $0.4 \mu \mathrm{m}$ and $100 \mu \mathrm{m}$ and $24.55 \%$ of remain was particles with $\varnothing>100-1000 \mu \mathrm{m}$ or the whole particles were dominated by particles with $\varnothing<100 \mu \mathrm{m}$.

Concentrate of fermented spinach produced via MF membrane process in Figure $8 \mathrm{~b}$ indicated particles with $\varnothing$ between 0.4 and $1 \mu \mathrm{m}$ or $<1 \mu \mathrm{m}(5.21 \%)$, particles with $\varnothing<10 \mu \mathrm{m}$ or between 0.4 and $10 \mu \mathrm{m}(73.7 \%)$, particles with $\varnothing<100 \mu \mathrm{m}$ or between 0.4 and $100 \mu \mathrm{m}$ (100\%) and particles with $\varnothing<1000 \mu \mathrm{m}$ or between 0.4 and $1000 \mu \mathrm{m}(100 \%)$ from $100 \%$ volume of material. In other words, $73.7 \%$ of concentrates was particles with $\varnothing$ between $0.4 \mu \mathrm{m}$ and $100 \mu \mathrm{m}$, and $26.3 \%$ of concentrate was particles $>100-1000 \mu \mathrm{m}$ or the whole particles were dominated by particles with $\varnothing<100 \mu \mathrm{m}$.
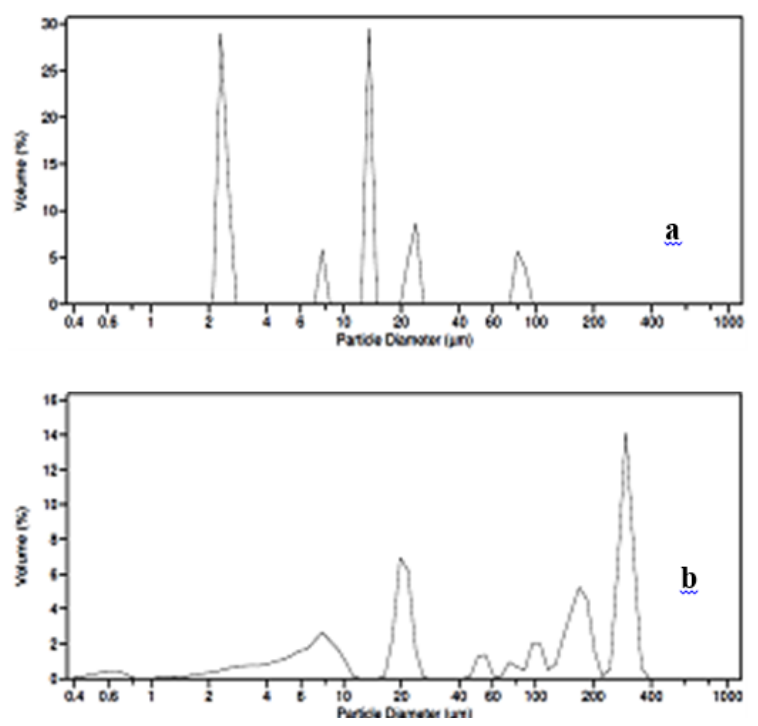

Fig.7 Particles distribution on fermented broccoli (feed) (a) and fermented broccoli concentrate powder (b).

Difference in particles size was possibility caused by contribution of particles size reduction as a consequence of MF membrane process. Its occurrence of interaction amongst particles by driving force at stirrer rotation speed $400 \mathrm{rpm}$, room temperature and pressure $40 \mathrm{psia}$ for 30 minutes causes a part of particles broken to smaller size, like process of size reduction. Biomass of fermented spinach is a group of particle components and microbes (fungi, yeast, bacteria) which have various particles size. Its composition showed a domination of polyphenol derivatives with molecular weight (MW) between 191.08 Dalton (Da.) and 192.78 Da., and total acids organic as Lactic Acid derivatives with MW from 251.13 Dalton (Da.) to 252.14 Da. or particles size with $\varnothing<1 \mu \mathrm{m}[9]$.
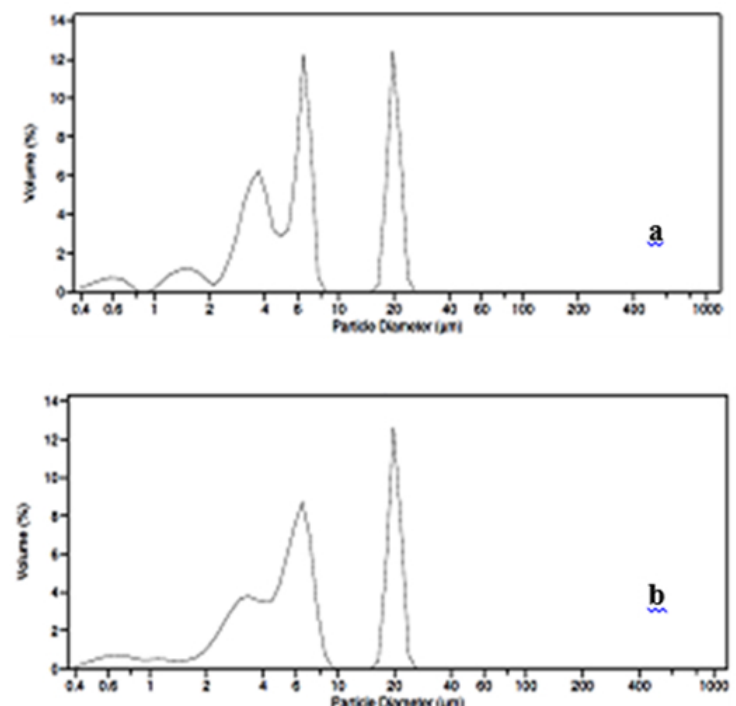

Fig. 8 Particles distribution on fermented spinach (feed) (a) and fermented spinach concentrate (b). 


\section{Conclusion}

DESMFC mode was able to separate and recover folic acid in both fermented broccoli and spinach concentrates 0.65 folds and 1.07 folds, respectively when compared to feed and retain more total solids, folic acid, and reducing sugar in concentrate. Drying process increased total solids, folic acid, total acids and reducing sugar, but decreased total polyphenol in both fermented broccoli and spinach concentrate powders produced via MF membrane process. Based on recovery of folic acid, optimization of MF membrane and drying processes was achieved by type of fermented spinach and gave concentrate and powder with compositions of total solids $6.29 \%$ and $96.91 \%$, total polyphenol $0.25 \%$ and 0.06 $\%$, folic acid $58.8 \mu \mathrm{g} / \mathrm{mL}$ and $54.33 \mu \mathrm{g} / \mathrm{mL}$, reducing sugar $105.34 \mathrm{mg} / \mathrm{mL}$ and $441.39 \mathrm{mg} / \mathrm{mL}$, and total acids $0.57 \%$ and $2.33 \%$, respectively. While, fermented broccoli gave concentrate and powder with compositions of total solids $5.76 \%$ and $94.37 \%$, total polyphenol $0.06 \%$ and $0.04 \%$, folic acid $28.1 \mu \mathrm{g} / \mathrm{mL}$ and 36.39 $\mu \mathrm{g} / \mathrm{mL}$, reducing sugar $66.1 \mathrm{mg} / \mathrm{mL}$ and $412.18 \mathrm{mg} / \mathrm{mL}$, and total acids $0.93 \%$ and $4.67 \%$, respectively. Concentrates of fermented broccoli and spinach gave particles distribution with diameter size $(\varnothing)$ between 0.4 and $100 \mu \mathrm{m}$ of $75.45 \%$ and $73.7 \%$, and particles distribution with $\varnothing$ between $100-1000 \mu \mathrm{m}$ of $24.55 \%$ and $26.3 \%$, respectively. Whereas, biomass of fermented broccoli and spinach without MF membrane process gave particles distribution with $\varnothing$ between 0.4 $100 \mu \mathrm{m}$ of $47.5 \%$ and $74,1 \%$, and particles distribution with $\varnothing$ between $100-1000 \mu \mathrm{m}$ of $52.5 \%$ and $25.9 \%$, respectively.

\section{References}

[1] Anonymus. 2012. Dietary Supplement Fact Sheet : Folate, Office of Dietary Supplements, National Institutes of Health. http://ods.od.nih.gov/factsheets/folate.asp, Accessed 8 December 2014.

[2] Susilowati, A., Aspiyanto, Maryati, Y., and Melanie, H. 2016 Research/Jurnal Penelitian Teh dan Kina. Vol. 19, No 1, pp. 67 - 84, P-ISSN 14106507, E-ISSN 2527-2942, 544/AU2/P2MILIPI/06/2013.

[3] Jayabalan, R., Subathradevi, S., Marimuthu, M., Sathshkumar, and Swaminathan, K. 2008. Changes in free-radical scavenging ability of kombucha tea during fermentation, Food Chem., 2008, 109 (1) 227 -234 .

[4] Dufresne, C. and Farnworth, E. 2000. Tea, kombucha, and health : a review, Food Res. Int., 33 (6), $409-421$.

[5] De Crécy-Lagard V., El Yacoubi B., de la Garza R.D., Noiriel A., and Hanson A. D. Comparative genomics of bacterial and plant folate synthesis and salvage : predictions and validations, BMC Genomics. 2007, $8: 245$.

[6] Hauser, P. M. and Macreadie, I. G. 2006. Isolation of the Pneumonic carinii dihydrofolate gene and functional compllementation in Saccharomyces cerevisiae, Federation of European Microbiological Societies Lett 256 (2006) 244 - 250, Published by Blackwell Publishing Ltd.

[7] Malbasa et al. 2008. Comparison of the product of kombucha fermentation on sucrose and molasses. Food Chem. 106 (3), 1039 - 1045.

[8] Quilivan, E. P., S. Roje, G. Basset, Y. Shahar-Hill, J. F. Gregory, and A. D. Hanson. 2003. The Folate precursor $\rho$-aminobenzoate is reversible converted to is glucose ester in the plant cytosol. J. Bio. Chem. $278: 20731-20737$.

[9] Susilowati, A., Iskandar, Y. M., Melanie, H., Maryati, Y., Lotulung, P. D., Aryani, D. G. 2015. Pengembangan Konsentrat Sayuran Hijau dan Kacang-kacangan Terfermentasi pada jagung (Zea mays L.) pramasak sebagai sumber asam Folat untuk formula pangan pintar. Laporan Hasil Penelitian, Program Tematik, Kedeputian IPT, Tahun Anggaran 2015, Pusat Penelitian Kimia LIPI, PUSPIPTEK, Serpong, Tangerang Selatan.

[10] Mulder, M. H. V. 1996. Basic Principles of Membrane Technology, Kluwer Academic Publishers, Dordecht, The Nederlands.

[11] Cheryan, M. 1992. Membrane Technology in Food Bioprocessing, In : R. P. Singh and M. A. Wirakartakusumah, Advances in Food Engineering, CRC Press Inc., Boca Ratan, Florida.

[12] Anonymous. 2000. Catalogue and Manual of Stirred Ultrafiltration Cells, Amicon Bioseparations, MILLIPORE, U.S.A.

[13] Association of Official Analytical Chemists. 1995. Official Methods of Analysis, Washington, D. C.

[14]Liu, Z. 2006. New techniques for tea catechins extraction, in : International Training Workshop of Tea Science, Hunan Agricultural University. China, 21 July - 10 August.

[15] Ruengsitagoon, W. and Hattanat, N. 2012. Simple spectrophotometric method for determination of folic acid, The 4th Annual Northeast Pharmacy Research Conference, Thailand.

[16] Keith Scott. 1998. Handbook of Industrial Membranes, 2nd. Edition, Elsevier Advanced Technology, Oxford, 763, 766, $767 \& 768$.

[17] Gilles J. C., Basset, Eoin P., Quinlivan, Jesse F. Gregory III and Andrew D. Hanson. 2005. Folate Synthesis and Metabolism in Plants and Prospects for Biofortification, CROP SCIENCE. Vol 45 : 449 -453 , Crop Science Society of America 677 S. Seoe Rd. Madison. WI 53711 USA. Accessed 18 December 2015. 